The End of

Globalization 



\title{
The End of Globalization
}

\section{Lessons from the Great Depression}

\author{
Harold James
}

HARVARD UNIVERSITY PRESS

Cambridge, Massachusetts

London, England 
Copyright () 2001 by the President and Fellows of Harvard College All rights reserved

Printed in the United States of America

Fourth printing, 2002

First Harvard University Press paperback edition, 2002

\section{Library of Congress Cataloging-in-Publication Data}

James Harold.

The end of globalization : lessons from the Great Depression / Harold James.

$$
\text { p. } \mathrm{cm} \text {. }
$$

Includes bibliographical references and index.

ISBN 0-674-00474-4 (cloth)

ISBN 0-674-01007-8 (pbk.)

1. International economic relations. 2. International trade.

3. International finance. 4. Depressions-1929. 5. Financial crises.

6. National state. 7. Globalization-Economic aspects. I. Title.

HF1359 .J35 2001

337-dc21 00-054157 